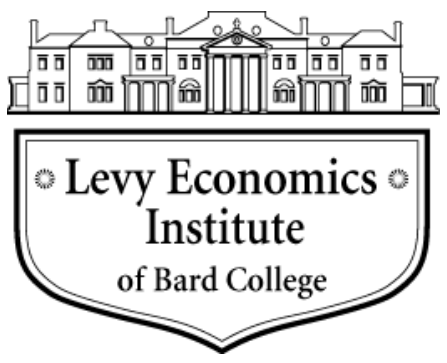

Working Paper No. 981

\title{
What Jobs Should a Public Job Guarantee Provide? Lessons from Hyman P. Minsky
}

by

\author{
Daniel Haim* \\ Levy Institute
}

January 2021

* The author would like to thank L. Randall Wray, Michael Ertl, and Diana Witzani for thoughtful comments and suggestions.

The Levy Economics Institute Working Paper Collection presents research in progress by Levy Institute scholars and conference participants. The purpose of the series is to disseminate ideas to and elicit comments from academics and professionals.

Levy Economics Institute of Bard College, founded in 1986, is a nonprofit, nonpartisan, independently funded research organization devoted to public service. Through scholarship and economic research it generates viable, effective public policy responses to important economic problems that profoundly affect the quality of life in the United States and abroad.

\author{
Levy Economics Institute \\ P.O. Box 5000 \\ Annandale-on-Hudson, NY 12504-5000 \\ http://www.levyinstitute.org
}

Copyright (C) Levy Economics Institute 2021 All rights reserved

ISSN 1547-366X 


\begin{abstract}
The job guarantee is a viable policy option for tackling both unemployment and underemployment. Hyman P. Minsky was one of the seminal writers on this subject. The first part of this working paper provides a survey of Minsky's writings to identify what kind of jobs he had in mind when recommending employer-of-last-resort policies. Minsky favored: (1) jobs increasing socially useful output, providing all of society better public services and goods; (2) jobs guaranteed by the public sector on a project-by-project basis at a minimum wage; (3) jobs in the places where people need them; and (4) jobs taking the people that need them as they are. The second part of the paper suggests policy recommendations for today's economy. As long as the COVID-19 pandemic still rages on, a targeted public job guarantee program can assist in the social provisioning and distribution of food, shelter, and medical services. After the pandemic, a public job guarantee can reduce poverty and inequality, and bring about a more democratic, sustainable, and socially cohesive economic system.
\end{abstract}

KEYWORDS: Job Guarantee; Public Service Employment; Employer of Last Resort (ELR); Unemployment; Full Employment; Minsky; Policy Design; COVID-19

JEL CLASSIFICATIONS: B31; E24; E61; H41; H53; I38; J21; J45; J68 


\section{INTRODUCTION}

Instability and with it what Orwell called "the haunting terror of unemployment" is the damning weakness of capitalism. (Minsky 2008b, 329)

Following the COVID-19 pandemic, governments around the world have started to implement far-reaching social policies to alleviate the effects of what is set to become the largest economic recession since World War II (World Bank 2020). A public job guarantee is among the ideas that have garnered renewed interest in the United States and abroad. India's Mahatma Gandhi National Rural Employment Guarantee Scheme has helped push rural joblessness down to 7.3 percent in June 2020, with 33 million households benefitting from the scheme in May 2020 (Times of India 2020). In the United States, Congresswomen Bonnie Watson Coleman (D-NJ) and Ilhan Omar (D-MN) have announced the introduction of the Workforce Promotion and Access Act (WPA Act 2020). Their proposal calls for the US Department of Labor to establish a job guarantee for states, localities, and tribal entities where the unemployment rate is greater than 10 percent or double the national unemployment rate. Public support for a job guarantee has been high, even before the current crisis, with approval ratings of up to 78 percent among US voters (The Hill 2019).

Many advocates for the job guarantee build on the work of Hyman P. Minsky. Minsky became famous for his contributions on the financial instability hypothesis, with many economists referring to the 2007-8 financial crisis a "Minsky moment." However, Minsky also published numerous articles and papers on how to effectively end poverty in the United States. Inspired by Franklin D. Roosevelt's New Deal reforms that focused on job creation in the 1930s, he proposed full employment policies that offer anyone willing to work a guaranteed minimumwage job. Minsky envisioned the government to be an employer of last resort, ${ }^{1}$ analogous to the central bank's function as a lender of last resort. With recent unemployment numbers at

\footnotetext{
${ }^{1}$ Minsky used different terms to describe the job guarantee, e.g., "employer of last resort" and "tap employer" (Minsky 2013, 39), "guaranteed job program" (Minsky 1987), and "infinitely elastic demand for labor [...] created by government" (Minsky 2008b, 343). He also used the names of New Deal programs synonymously. Bill Mitchell coined the term "buffer stock employment model" for a similar approach (Mitchell 1998). In recent years, the terms "job guarantee" and "public service employment" have become more widely used (Kaboub 2007; Wray et al. 2018).
} 
unprecedented heights, the introduction of a public job guarantee could be another Minsky moment.

The job guarantee was a macroeconomic necessity to Minsky. "Big government," as he called it, provides floors and ceilings to the booms and bust of the business cycle. A full employment policy would reduce instability while supporting price stability. However, Minsky also viewed unemployment as a moral evil that democratic societies need to remedy. He was critical of welfare payments as a strategy to combat poverty, often repeating that "a dole is anathema: a bad thing"2 (Minsky 1994a).

This working paper not only summarizes Minsky’s moral and economic arguments for a job guarantee but also suggests what type of jobs a public job guarantee should provide. Drawing on the rich sources in the Hyman P. Minsky Archive at the Levy Economics Institute of Bard College, I want to examine what jobs Minsky had in mind when formulating his full employment policies.

In the second part of the paper I discuss the implications of these ideas for today's economy. During the COVID-19 pandemic, a targeted public job guarantee program can assist in the social provisioning and distribution of food, shelter, and medical services. Parents that need to stay at home to help school their kids or have care duties can also be employed. After the pandemic, a public job guarantee can reduce poverty and inequality, and bring about a more democratic, sustainable, and socially cohesive economic system.

The current unprecedented economic crisis calls for unprecedented policy answers. Minsky's framework for a public job guarantee offers a useful toolkit to draw from.

\footnotetext{
2 "Dole" is a common informal expression for unemployment benefits paid out by the government.
} 


\section{WHAT WERE MINSKY'S MORAL ARGUMENTS FOR A JOB GUARANTEE?}

Minsky based his argument for the job guarantee on his moral foundation. In his opus magnum, Stabilizing an Unstable Economy, he writes that "[e]conomic policy must reflect an ideological vision; it must be inspired by the ideals of a good society" (Minsky 2008b, 9).

Minsky believed that something was fundamentally wrong with our capitalist economies. He was not a revolutionary in a Marxist sense, but clearly a leftist in US academia. His main academic influences, aside from John Maynard Keynes, were institutionalist economists at the University of Chicago at a time when economics was taught as "part of the study of society, where economic history, political science, sociology, anthropology and economics were part of an integrated sequence aimed at understanding modern society” (Minsky 1988, 172).

In a short paper about May Day in 1986, Minsky provided a good summary of his moral approach: "The essential radical view is that work is a good thing, and that chronic mass unemployment is a flaw of the economic order, not a flaw of the unemployed. Work is a public good, for only if work is available does a human achieve the dignity and self-respect that makes a person a good citizen" (Minsky 1986, 4).

On a societal level he believed that "if the economy provides basic security and a sense of personal worth for all — because work is available for all—many social problems will recede to manageable proportions" (Minsky 2008b, 3).

Minsky's moral arguments for the reduction of poverty and inequality revolved around the themes of dignity and self-respect, social justice, civil standards of an open liberal society, democracy, and social cohesion. Minsky was critical of welfare, especially of unemployment benefits for people willing to work, both from the perspective of the recipients and from the perspective of the state. The state, Minsky argued, chooses welfare over other policies because it seems cheaper: "Welfare, in the form of aid to families with dependent children, exists because it is the cheapest way, short of a policy to let them die, of taking care of the population in want. Foster homes, orphanages, and guaranteed work for parents are all more expensive. Full 
employment is the civilized and humane way of getting rid of welfare as we have known it..." (Minsky 1996, 365).

The New Deal's work programs inspired his alternative approach to full employment policies. In his notes for a workshop held on "Ethics and Capitalism" at the Levy Institute in November 1994, he wrote, "An ethical foundation of the New Deal version of State Capitalism. A: No one will starve in America. B: A dole is anathema: a bad thing. A and B imply WPA, NYA, CCC ${ }^{3}$ as the foundation stones of macroeconomic policy" (Minsky 1994a). In an article coauthored with Institute President Dimitri B. Papadimitriou in the same year he states both "an abhorrence of the dole and the importance of income from work as supporting the dignity of individuals" as the main motivation for a job program. He claimed that "[t]he first aim of an employing America program should be to assure that every American has a job which pays at least the minimum wage" (Papadimitriou and Minsky 1994, 24).

The theme of dignity also appears in his earlier writings when he discusses relative and absolute poverty. Minsky uses a negative frame of the perception of the "dole" to juxtapose it with a positive frame of income derived from work: "Part of the poverty problem in the United States centers around the social and personal reaction to how income is received. The welfare recipient can be poor, even if welfare standards are adequate, if cash income derived from welfare is personally and socially demeaning" (Minsky 2013, 63).

Dignity is derived from earning income through productive work, which increases a person's self-worth and ability to support their family. Minsky did not write much about dignity at the workplace itself (e.g., dignified labor standards).

Minsky wrote several contributions relating to job guarantee policies when he was working with labor economists on social policy during the Kennedy/Johnson era in the 1960s. He considered the Kennedy/Johnson administration's War on Poverty as failing since the policies did not focus on job creation. He believed that "the single most important step toward ending poverty in

\footnotetext{
${ }^{3}$ The Works Progress Administration (WPA), the National Youth Administration (NYA), and the Civilian Conservation Corps (CCC) were public work programs created by the US federal government as part of the second New Deal in the 1930s.
} 
America would be the achieving and sustaining of tight full employment. [...] [T] here is no better cure for poverty than family income, especially family income earned on a job" (Minsky 2013, 3).

During that time, he framed the need for social policy as necessary "to assure domestic peace and tranquility" (Minsky 2013,28). Minsky claimed that an antipoverty strategy based on unemployment benefits would be socially unsustainable, as those receiving it are dependent on the dole: "[T]he creation of a large class of social remittance men and women is not conducive to either social cohesion or domestic tranquility" (Minsky 2013, 29-30). He returned to this line of thinking in Stabilizing an Unstable Economy: "Compensation for work performed should be the major source of income for all. Permanent dependence on expanding systems of transfer payments that have not been earned is demeaning to the recipient and destructive of the social fabric. Social justice and individual liberty demand interventions to create an economy of opportunity in which everyone, except the severely handicapped, earns his or her way through the exchange of income for work. Full employment is a social as well as an economic good" (Minsky 2008b, 10).

He went so far as to state that welfare payment schemes can be a threat to democracy: "A full employment economy is supportive of democracy whereas an economy based on transfer payments supports resentment" (Minsky 1996, 368).

However, Minsky did not disdain all kinds of welfare payments. For the people not expected to be in the labor force he envisioned a "generous scheme of transfer payments" (Minsky 2013, 27). Minsky did not specify whom he meant exactly. A reasonable job guarantee policy today could also provide people with handicaps, people with disabilities, and other groups of people meaningful work opportunities. As for transfer payments, he favored child allowances in the form of cash transfers since tax reductions would only support those with taxable income. These transfers should be without means tests, to eliminate the stigma for recipients. For the United States he also proposed the introduction of universal medical care (Minsky 2013, 25). ${ }^{4}$

\footnotetext{
${ }^{4} \mathrm{He}$ returned to his argumentation for Medicare for all in the 1990s, this time because of his analysis of the dynamics of capitalism: "A universal access health system and vested defined contribution pension systems to
} 
Minsky's idea for a job guarantee is presented as an opportunity to work, not as coercion to work, offering jobs "of the right kind, at the right place, and with sufficiently high incomes so that all who are willing and able to work can earn enough from jobs to maintain themselves and those for whom they are responsible at a level above some poverty line" (Minsky 2013, 3). The job guarantee is voluntary. As Minsky put it, "sane adults should be free to choose poverty, but no one should have poverty thrust upon him" (Minsky 2013, 3).

A public job guarantee policy yields perceptible benefits to all members of society through improved parks, public safety, better education, etc., enabling democratic leaders to gain support for such a program even from people not directly threatened by unemployment. Minsky thought it was important that all members of society benefit from such a large program. He feared political backlash by more affluent parts of society against a program that would equalize the income distribution. Therefore, Minsky thought it was imperative that a job guarantee program produced socially useful output, as "public goods may provide the vehicle by which self-interest is consistent with income equalization" (Minsky 2013, 77). However, Minsky also argued that social policy must deliver what it promises since "[h]opes raised then dashed are a clear danger to the fabric of society" (Minsky 2013,46).

Minsky believed that good economic policy should create the conditions to sustain the civil and civilized standards of an open liberal society. He did not believe in trickle-down economics or the subordination of social goals to economic growth: "If amplified uncertainty, extremes of income distribution, and social inequality attenuate the economic underpinnings of democracy, then the market behavior that creates these conditions should be constrained. If it is necessary to give up a bit of market efficiency, or a bit of aggregate income, in order to contain democracythreatening uncertainty, then so be it" (Minsky 1996, 364). In other words, "We can afford to relinquish some output to achieve social justice and individual liberty" (Minsky 2008b, 9).

supplement social security. The job-related health care and pension systems are obsolete in today's competitive environment" (Minsky 1992b, 9). 


\section{WHAT WERE MINSKY'S ECONOMIC ARGUMENTS FOR A JOB GUARANTEE?}

Minsky always had a different view of how the economy works compared to the mainstream, as well as for whom it should work. He believed that a financial system ought to enable the capital development of the economy, and that capital development would lead to rising living standards.

Minsky believed that the Keynesian revolution in economic policy and theory had been aborted, which led to policy prescriptions impotent to deal with the problems we face in today's capitalist economies. He differentiated between two approaches by policymakers and economists: a "Smithian" and a "Keynesian" view. With Smithian he did not think of the classical economic approach by Adam Smith but rather the widespread market fundamentalist view of many neoclassical and neoliberal economists in the 1980s and 1990s:

\footnotetext{
This invisible hand proposition of Smith became the foundation not only of the orthodox economic theory of Marshall and Walras and therefore the foundation of the modern mathematical economics which reached its fulfillment in the now classic demonstration by Arrow and Debreau that a competitive equilibrium exists, that the equilibrium is a Pareto optimum and that it fulfills the Smithies criteria of promoting the public interest. A further inference that is drawn from Arrow Debreau, which is quite unwarranted, is that it is supportive of the ideology of laissez faire. (Minsky 1993b, 20-21)
}

To this view, exogenous reasons cause financial crises, and involuntary unemployment cannot exist since workers may always choose to work at a lower wage or to suspend union memberships.

Minsky, on the other hand, believed in the inherent instability of capitalism. He built on what he called the Keynesian view of the economy, with the financial system at the center of his analysis. Investment and financing processes, increased risk-taking in times of prosperity, the subsequent deterioration of private companies' balance sheets, and innovations in the financial sector that evade regulations are all endogenous mechanisms that cause financial crises. Minsky did not believe it would be possible to fine-tune the economy. Instead, he wanted regulators to realize the endogenous instability of capitalism as a financial system. 
To combat the inherent instability of capitalism, Minsky proposed a range of financial and economic reforms. He recognized early on the fragility and risk caused by the rise of securitization instruments in the 1980s and 1990s. He attributed innovations in the financial sector to profit-seeking behavior, often leaving regulators and the central bank blindsided. He was also critical of economic policy that solely focused on growth, believing that this was simply bad policy: "The emphasis on investment and 'economic growth' rather than on employment as a policy objective is a mistake. A full-employment economy is bound to expand, whereas an economy that aims at accelerating growth through devices that induce capitalintensive private investment not only may not grow, but may be increasingly inequitable in its income distribution, inefficient in its choices of techniques, and unstable in its overall performance" (Minsky 2008b, 325).

Policy should focus on the public purpose, dealing with the fundamental flaws of capitalism. Minsky identified three fundamental flaws: unemployment and inequality (which Keynes had already identified), as well as instability. Minsky was critical of giant corporations and giant banks, which he thought had become stagnant and inefficient. Instead, he preferred an economic and financial system with smaller banks that fosters smaller entrepreneurial organizations and firms, shared knowledge across industries, more competitions within markets, and limits to the size of capital-intensive firms. He envisioned policies that made economies more stable while also maintaining full employment: "An economy in which leading sectors are socialized, ${ }^{5}$ in which communal consumption satisfies a large proportion of private needs, in which taxation of income and wealth is designed to decrease inequality, and in which speculation in liability structures is limited by laws that determine permissible liability structures might well achieve a

\footnotetext{
${ }^{5}$ Keynes argued that the influence of banking policy on the rate of interest will not be sufficient to determine an optimum rate of investment. He argued that the socialization of investment "will prove the only means of securing an approximation to full employment" (Keynes 1997, 378). Keynes did not, however, advocate for public ownership of the means of production, but rather for central controls and cooperation with the private sector. Minsky identified an inconsistency between Keynes's belief that investment must be socialized to achieve full employment and his view that the market efficiently allocates resources so that private ownership can be retained. Minsky called the post-World War II policy of creating a high-profit, high-investment economy in which taxes and government spending are evaluated based on their impact upon private investment rather than on consumption or income equality "socialism for the rich" (Minsky 2008a, 156). Minsky (2008a, 164) believed that the socialization of leading sectors is "fully compatible with a large, growing, and prosperous private sector" and conductive to greater freedom for entrepreneurial ability compared with the high-investment, high-profits policy that favors giant firms.
} 
close approximation to sustained full employment without the tensions and instabilities that are inherent in the current policy strategy" (Minsky 2008a, 164).

To attenuate instability and uncertainty, big government is necessary. The government provides floors and ceilings to the booms and bust of the business cycle through automatic stabilizers and regulations. Minsky believed that government spending "must be big enough to ensure that swings in private investment lead to sufficient offsetting swings in the government's deficit so that profits are stabilized" (Minsky 2008b, 330).

Big government comes in many forms. One of Minsky's sayings was that there are as many varieties of capitalism "as Heinz has of pickles" (Minsky 1994b, 1). He held that it is necessary to "distinguish among big governments which are military states, which rely upon transfer payments and those that emphasize resource development" (Minsky 1994b, 2), favoring the third type.

For the United States he believed that government expenditure should be about 20 percent of gross national product (GNP). At that time, he believed that a job guarantee would only take up 1.25 percent of full-employment GNP, compared to Social Security's budget of 4.8 percent and a national defense budget of 5.9 percent of the estimated full-employment GNP in 1983 (Minsky 2008b, 334-35).

Minsky believed that an integral part of a government's ability to stabilize the economy was its ability to guarantee full employment, since "[f]ull employment is a way of attenuating uncertainty" (Minsky 1996, 366). In Stabilizing an Unstable Economy, Minsky expands on the idea of the government serving as employer of last resort:

The policy problem is to develop a strategy for full employment that does not lead to instability, inflation, and unemployment. The main instrument of such a policy is the creation of an infinitely elastic demand for labor at a floor or minimum wage that does not depend upon longand short-run profit expectations of business. Since only government can divorce the offering of employment from the profitability of hiring workers, the infinitely elastic demand for labor must be created by government. [...] [T] he employment programs are to be permanent, operating at a base level during good times and expanding during recession [...]. (Minsky 2008b, 343) 
Minsky's job guarantee functions like other automatic stabilizers, serving as a buffer stock for employment: "Once the shift to an employment program has been assimilated, cyclical variations in employment will be replaced by variations in the proportions of workers [in the job guarantee]. When demand for labor by private employers increases, the proportion of workers [in the job guarantee] will decrease" (Minsky 2008b, 348).

A public job guarantee policy enables the government to effectively set the minimum wage. If a private company does not offer a job at the public minimum wage, then a worker may always leave the private job for the public option. This will put pressure on employers to increase their wages to the minimum wage. Thus, workers have the power to choose and bargain for a minimum wage job. If the public minimum wage is set at a higher rate, this will lead to a higher share of workers in the public sector.

A final macroeconomic argument for the public job guarantee is the question of inflation. Minsky pointed out that social policies that focus on cash transfers (universal basic income in the form of a negative income tax, food stamps, etc.) mainly drive inflation instead of achieving their goals of reducing poverty. Minsky argued in the 1960s that a job guarantee policy might also induce inflationary pressure if the productivity of low-wage workers did not keep up with wage growth while wages in high-wage industries rose at the same pace as productivity (Minsky 2013, 8-9). However, Minsky believed these problems to be manageable. He was also aware of wage-led inflation, noting that the job guarantee "must not unduly decrease the supply of labor to other occupations and employers, creating upward pressure on wages" (Minsky 2008b, 345).

\section{WHAT KIND OF JOBS FOR WHOM?}

What kind of jobs did Minsky envision when he proposed a public job guarantee? He favored: 1) jobs increasing socially useful output, providing all of society better public services and goods; 2) jobs guaranteed by the public sector on a project-by-project basis at a minimum wage; 3) jobs in the places where people need them; and 4) jobs taking the people that need them as they are. 


\section{Jobs Producing Socially Useful Output}

First, Minsky had a clear view that public jobs should produce socially useful output. Minsky was critical of the fact that military spending accounted for a big portion of public expenditure that increased aggregate demand in the 1960s and the 1980s. He did not consider military spending as necessarily useful output: "We can assume that for many Americans the perceived benefits from foreign adventures, military procurement, and space spectaculars are less, per dollar of expenditure, than from private procurement and public goods such as schools, parks, and safety on the streets" (Minsky 2013, 46).

Instead, he based his policy proposals on the New Deal programs such as the CCC, NYA, and WPA. In the 1930s, these programs promoted resource utilization by direct employment in the form of public works, rural electrification, the Tennessee Valley Authority and other river harnessing projects, the tree belt, reforestation, and public housing (Minsky 1992b, 6). Minsky envisioned a modernized WPA that also focused on education and the care sector, "[providing] supplementary labor to schools, hospitals, park systems, etc. It can build public facilities like swimming pools, tennis courts, etc." (Papadimitriou and Minsky 1994, 25). The object of a job guarantee should be to "improve parks, build recreation facilities, maintain schools, provide day care, etc." (Minsky 1987), extending the original New Deal programs into sectors where women are disproportionately affected.

One of Minsky's analysis focuses on the evolution of capitalism. He described what we call neo-liberalism today as "money manager capitalism." ${ }^{6}$ He recognized the uncertainty and instability that came with increased securitization and speculations on Wall Street. Minsky favored small and medium-sized banks, considering them as more profitable than larger banks. He also favored jobs in small and even micro-sized businesses over listed firms "whose future is dependent upon the vagaries of money managers' evaluation" (Minsky 1996, 367). This means

\footnotetext{
${ }^{6}$ In his later years, Minsky developed his own stages approach of capitalism. For the United States he identified five distinct financial stages, evolving over time: "commercial capitalism; industrial capitalism and wild cat financing; financial capitalism and state financing; paternalistic, managerial, and welfare state capitalism; money manager capitalism" (Minsky 1996, 362). In money manager capitalism, "the proximate owners of a vast proportion of financial instruments are mutual and pension funds. The total return on the portfolio is the only criteria used for judging the performance of the managers of these funds, which translates into an emphasis upon the bottom line in the management of business organizations. It makes the long view a luxury that only companies which are essentially owned by a single individual and which are not deeply dependent upon external financing can afford" (Minsky 1996, 358-59).
} 
that for private-public partnerships that might evolve out of job guarantee programs he would have favored collaborations with smaller, regional firms over giant corporations. This is also in line with his view of supporting more labor-intensive forms of employment.

Minsky understood that job guarantee policies reduce poverty through the supply of goods and service for public consumption. This means that programs should provide improved goods and services to the poor and society as a whole. In 1987, Minsky outlined this approach in a column written for the St. Louis Journalism Review, commenting on the "Guaranteed Job Opportunity Program" proposal of US Senator Paul Simon (D-IL):

\footnotetext{
Our standard of life depends only partly on our private incomes, for we "consume" the services of parks, schools, safe streets, and a wealth of other amenities. [...] The Job Opportunities Program should make it possible to improve the amenities in communities throughout the country and to protect and improve our common heritage. Poverty in the United States stems as much if not more from shortcomings in communal services, what [John Kenneth] Galbraith once called public squalor, as from shortfalls in private income. If we make adequate communal consumption available to all, much of the burden of poverty can be eased. (Minsky 1987)
}

\section{Publicly Guaranteed Jobs Offered by Different Levels of Government}

Second, Minsky envisioned publicly guaranteed jobs offered by different levels of government. Again, he modeled his ideas after the New Deal programs: "Full employment requires special employment programs of the federal, state, and local governments. The New Deal programs that provided income in exchange for work that led to community building - the Works Progress Administration, the Civilian Conservation Corps, and the National Youth Administration — need to be considered as the basis for social policy in the United States” (Minsky 1996, 366).

He stressed that the WPA, CCC, and NYA were project oriented and that they were of a makework nature only in the emergency startup phase (Minsky 1992b, 6). However, Minsky did not simply call for the reintroduction of the New Deal work programs, writing that "[w]e should not think of simply replicating the 1930s CCC, NYA and WPA: these 1930s mechanisms can best serve as prototypes" (Minsky 1993a, 5). Ultimately, he saw the federal government as "the guarantor of full employment and a partner of private enterprise in the creation of resources" (Minsky 1992c, 4). 
To qualify for employment all that would be necessary is the will to work at the national minimum wage and to register at the local public employment office. The job offers would come from various national government agencies, as well as from local and state government agencies. They would "bid for labor by submitting their projects, and a local 'evaluation' board would determine priorities among projects" (Minsky 2013, 21).

\section{Jobs in Places Where People in Need Live}

Third, Minsky envisioned jobs in the places where people in need lived. This means that people would not need to move to urban areas to get a public job under his proposal. Broadly speaking Minsky advocated that income from work must be available to all, noting, "the demand for labor must be infinitely elastic over a wide range of labor types and geographical regions" (Minsky 2008b, 345).

Minsky thought that his proposal would decrease work migration from rural to urban areas: "An employer of last resort, willing and able to hire all who offer to work, will have a large impact on the poorer rural areas. One effect of such a national employment policy will be to slow down the pace of migration to the urban complexes" (Minsky 2013, 40).

\section{Taking People as They Are}

Fourth, Minsky argued repeatedly that a job guarantee program needs to take people as they are. After all, unemployment was a failure of capitalism, not of the unemployed. Successful antipoverty measures thus cannot focus on retraining or reeducation alone. Minsky took the example of people at the highest risk of poverty: "Programs must be designed which hold out a promise of a useful and productive life for our high school dropouts" (Minsky 2013, 20).

To supply meaningful jobs for those with low skills or education, Minsky recommended breaking complex jobs down into simpler jobs, giving the example of using park patrolmen as supplements to completely trained police (Minsky 2013, 19). Projects should be designed to use existing abilities; this also applied to high-skilled workers who may lose their jobs because of technical or program changes. Minsky argued that a skilled worker would suffer a capital loss "equivalent to the loss by fire of an uninsured house" (Minsky 2013,24) if no other equivalent job was available. 
Minsky believed that a job guarantee should "target specific types of unemployed" (Minsky 1992a, 10) and must deal specifically "with youth and adult employment as well as the provision of jobs for older adults" (Minsky 2008b, 345). He thought that the problem of youth unemployment called for a specific agency, modeled after the NYA, for the target population between 16 and 22 years of age. One of his ideas was to create a school aid program that employed high school and college students as gym and recreational aids.

Since Minsky was interested in contemporary changes in both the financial and real sectors of the economy, he also understood how fast the labor market was changing. Commenting on the falling share of the labor force in the secondary sector, he argued that there is "a need to support more workers in the production of socially useful outputs that are not manufactured goods and where the costs may not be recoverable by any simple fee-for-services arrangements" (Minsky 1994c, 23).

Another change in the labor market he analyzed was the fact that employees increasingly changed their jobs and companies a number of times over the interval between school and retirement. He advocated for the expansion of community colleges, which he believed served communities and made adult education a real possibility (Minsky 1995).

Minsky also provided a thought experiment of introducing a standard four-hour workday for every job. This would introduce the flexibility for agile people to combine two regular jobs if needed, while older people who cannot keep up with the pace of certain work can remain in their jobs if they only work four hours a day. Minsky saw the four-hour workday as a chance to easier achieve full employment. It would also allow adults to retrain and would "breed ambition and commitment" (Minsky 1986). However, Minsky never incorporated the four-hour workday in detail into his job guarantee proposals. He also did not specify how the wage structure would change if a four-hour workday would be introduced, or if one four-hour workday job would pay a sufficient wage to support a family.

He did believe that a job guarantee might have to develop part-time work programs "because it will provide supplementary income to older adults as well as income for women with childcare responsibilities" (Minsky 2008b, 347). 


\section{WHAT CAN WE LEARN FROM MINSKY TODAY?}

Minsky believed that capitalism is inherently unstable, but he also believed public institutions attenuate booms and busts. His public job guarantee proposals aimed at building institutions that could end poverty in the United States without relying on welfare. However, he held that " $[t]$ he problem of discovering and putting in place the institutions of a successful capitalism cannot be solved once and for all" (Minsky 1994c, 26).

For a contemporary job guarantee proposal to be successful, we need to address the problems that arise out of the current mode of production. The financial crisis and recession of 2007-8 did not end neo-liberalism (Wray 2016, 161). COVID-19 and the global economic recession we are currently experiencing might change that.

However, for as long as the immediate health threat of the pandemic is not averted, a broad public job guarantee might not be the most suitable response. During the pandemic, the main policy problem we face is to reduce the spread of the virus. A job guarantee program is not a potent social policy if the goal is for everyone to stay at home from their jobs. Where the pandemic still ravages, the job of governments is to build confidence that it can meet two challenges: 1) that the public health threat can be overcome; and 2) that the resulting economic fallout will be dealt with in an equitable way.

Confronting the first challenge requires the social provisioning and distribution of food, shelter, and medical services, to provide "a guarantee not of income but of survival" (Kregel 2020). A targeted public job guarantee program can be used to support the production and distribution of essential goods and services. Packaging and delivering food and supplies to homebound people - quarantined people, sick people, those taking care of others - is a task that must be done as safely and reliably as possible. A job guarantee could provide the workers needed to fulfill these tasks.

In addition, a job guarantee could be implemented for parents that need to stay at home to provide childcare and educational support for their children. Many school districts switched to online learning in both the United States and Europe. Even if countries opened their schools for 
in-person classes, the threat of closings due to a spike in infection rates will continue for as long as there is no vaccination available. Those parents giving up a job to stay at home to help school their children — mostly women — could be employed for this service immediately and safely.

For the second challenge we can build on Minsky's moral and economic framework to create a public job guarantee for everyone willing and able to work. A job guarantee program can reduce poverty and inequality after the pandemic, including those previously left behind. We can organize it democratically and embed the program in a broader policy of caring for communities and the environment.

\section{Reducing Poverty and Inequality}

Minsky warned about rising inequality in money manager capitalism. Unfortunately, his prediction came true. In the past decades, we have seen drawn-out jobless recoveries and economic growth has mainly benefitted the wealthiest 10 percent since the 1980s. Rising inequality has also led to an increase in the share of the working poor. In 2018, seven million people in the United States - 4.5 percent of the labor force-were earning an income below the official poverty line (US Bureau of Labor Statistics 2020a). Following the recession of 2008, the share of the working poor increased to 7.2 percent in 2010. A similar rise will likely occur in the upcoming months.

To deal with these developments a job guarantee needs to set dignified labor standards. Ideas include doubling the federal minimum wage in the United States to $\$ 15$ per hour, guaranteeing health benefits, and reducing working hours to 35 hours of work per week with full-time pay and benefits (Tcherneva 2020). This would end the necessity to work several jobs to be able to pay rent in many parts of the United States and follow Minsky's main approach to ending poverty: through jobs, not welfare.

\section{Including Those Previously Left Behind}

Dignity and social justice were important themes to Minsky. While he did think of high school dropouts as one target group of a job guarantee, he did not write much about disadvantaged social groups or discrimination in the labor market. He made only general statements, e.g., that 
barriers need to be removed that "keep groups of people - the young, the aged, women, minorities—out of the job market” (Minsky 1979).

To be successful, a job guarantee today must take into account the complex structures of discrimination based on race, sex, gender, and nationality. For example, a job guarantee can provide a safety net and employment opportunities for former prison inmates in the United States. It can help provide a path to citizenship for migrants and refugees in Europe and "Dreamers" in the United States. A job guarantee can also include a childcare guarantee to help alleviate unpaid care burdens and reduce gender disparities in the labor market.

\section{A Democratic Bottom-Up Approach}

Minsky believed a job guarantee would be supportive of democracy because all members of society profit from reduced unemployment and the socially useful output the program would produce. He did not spend much time thinking about democratic processes within the program. To fill this gap, Pavlina Tcherneva $(2020,88)$ proposes a participatory democracy approach with a bottom-up design, "[...] encouraging direct input from citizens, community members, and other stakeholders representing the public interest in the proposal, management, and execution of the project. [...] Because the job guarantee program encourages citizen input, puts pressure on punitive private sector labor practices, and invests in the public good, it can be an institution with profound democratizing tendencies, functioning as a conduit for transformative change in the workplace, in people's everyday lives, and in the economy as a whole."

Combining the job guarantee with a democratic and decentralized bottom-up approach also tackles the issue of how to provide enough jobs in an economic downturn. Local communities and citizens provide suggestions regarding urgent, ongoing, and nice-to-have projects, and many existing local projects and initiatives could easily be scaled up.

\section{Embedding the Job Guarantee in a Green New Deal}

Along with the health crisis and the economic crisis, we are still facing a worsening climate crisis. We not only need to limit global temperature rise to 1.5 degrees Celsius but must also strengthen our ability to deal with the manifold impacts of climate change that are manifest today. 
What we need today is a Green New Deal combined with a public job guarantee to help rebuild our societies. The job guarantee can be envisioned as "National Care Act," with green jobs that address "all forms of destitution and neglect of our most valuable resources, both natural and human" (Tcherneva 2020, 93). We can combine our need to care for the environment with care for communities and care for people.

A Green New Deal with a job guarantee delivers relief by ensuring universal access to social safety and good healthcare, provides a just transition with a sustainable economic recovery, and offers democratic participation and agency in the process (Green New Deal for Europe 2020).

\section{Battling Unemployment and Underemployment Effectively after the Pandemic}

Unemployment in the United States stood at 6.7 percent in October 2020, affecting 11.1 million people and their families. The unemployment rate in October was still 3.4 percent higher than in February of the same year. The crisis affects minorities disproportionately, with unemployment rates of 10.8 percent for Blacks and 8.8 percent for Hispanics. Unemployment rates for teenagers stood at 13.9 percent, while 6.7 million people in the United States work part time for economic reasons but would prefer full-time employment Additionally, 6.7 million people left the labor force but wanted a job, which is 1.7 million more people than before the COVID-19 crisis (US Bureau of Labor Statistics 2020b).

In Europe, short-time work schemes in several countries have so far prevented mass layoffs, ${ }^{7}$ and unemployment numbers published by Eurostat might not yet present a complete picture of the crisis. ${ }^{8}$ The latest estimates for September 2020 indicate unemployment rates of 8.3 percent in the eurozone and 7.5 percent in the EU-27, amounting to around 16 million people (Eurostat 2020b). However, unemployment and underemployment were already high before the crisis. In 2019, 14.2 million people were unemployed, and another 14.9 million people were experiencing

\footnotetext{
${ }^{7}$ Short-time work schemes are job retention policies in which the government pays parts of wages and salaries under the condition that firms keep their employees. Around 50 million jobs were supported by job retention schemes in OECD countries by May 2020 (OECD 2020).

${ }^{8}$ Eurostat surveys follow the ILO definition of unemployment, asking people if they are available to the labor market in the upcoming two weeks. Because of lockdowns, many people are unable to resume work, therefore they are not officially counted as being unemployed. In addition, many people are not actively looking for jobs because they have to care for children during lockdowns.
} 
underemployment - either working part time, not looking for a job, or unable to start working immediately (Eurostat 2020a).

Cash transfers have been an important measure in alleviating some of the immediate financial distress caused by lockdowns and layoffs. Nonetheless, they are not appropriate for dealing with a pandemic in which money cannot be spent due to lockdowns or the subsequent rise in unemployment. While the pandemic is still a threat, a job guarantee could be used to support the safe production and distribution of essential goods and services to people that need to stay at home.

Massive corporate bailouts combined with increased welfare payments could leave us with another jobless recovery and increased inequality. We might face years of secular stagnation, with high rates of structural unemployment in both Europe and the United States.

Without a job guarantee and the threat of a potential expiration date on new transfer payments, this will inevitably lead to increased levels of poverty and inequality. Furthermore, this could develop into another major health crisis apart from COVID-19, as millions of workers in the United States have lost their employer-sponsored insurance ${ }^{9}$ and because the unemployment crisis further aggravates the US opioid crisis. ${ }^{10}$

A public job guarantee can address both the chronic structural unemployment that was afflicting Europe before the crisis and the large swings in unemployment we are witnessing due to the COVID-19 crisis in both the United States and Europe. The job guarantee is a superior choice to subsidies to private companies, since only the state can offer an infinitely elastic demand for labor. In addition, a public job guarantee offers all participants health coverage, thereby decreasing public health risks.

\footnotetext{
${ }^{9}$ A study by the Commonwealth Fund estimates that by June 2020, about 7.7 million workers had lost their employer-sponsored insurance. An additional 6.9 million dependents were also covered by these health plans (Fronstin and Woodbury 2020). Not all of these newly uninsured will be able to enroll in COBRA (Consolidated Omnibus Budget Reconciliation Act) continuous coverage, Affordable Care Act marketplace plans, or Medicaid. ${ }^{10}$ The United States has experienced a rise in what has been called "deaths of despair" (Case and Deaton 2020). Part of the problem is unemployment and labor force nonparticipation's correlation with drug overdose mortality (Rudolph et al. 2020).
} 


\section{CONCLUSION}

"The requirements for turning the country around in 1992 are the same as they were in 1933: a recognition that we are not resource constrained and the will to throw off the conservative ideology that has done such a disservice to our country" (Minsky 1992b, 10). What Minsky wrote in a reply to an article called "Is There a Democratic Economics?" still holds true in 2020.

Economic policy must be inspired by the ideals of a good society. Minsky was determined to end poverty in the United States. The slow recovery since 2008 has aggravated disparities within society. Now, the fallout from the COVID-19 pandemic is predicted to further increase inequality and poverty (Nassif Pires et al. 2020). With unemployment numbers at astronomical heights, we need more than corporate bailouts, subsidies, and direct cash transfers. As long as the pandemic still rages on, a targeted public job guarantee program can assist in social provisioning and the distribution of food, shelter, and medical services. Parents that need to give up their jobs to help school their children at home could be employed as well. When the threat of the virus subsides, we can create a public job guarantee for everyone willing and able to work. A public job guarantee could bring about a more civilized, democratic, and socially cohesive economic system that provides working families with a living wage, dignity, and selfrespect.

Economically, the public job guarantee serves as a buffer stock of employment, decreasing instability and stabilizing inflation. A job guarantee uses idle productive resources and provides public goods and services. Whereas better times for the rich rarely trickle down to the poor, "better times for the poor will [...] bubble up to the affluent" (Minsky 1987).

Minsky had a clear vision what jobs a public job guarantee should provide: 1) jobs increasing socially useful output, providing all of society better public services and goods; 2) jobs guaranteed by the public sector on a project-by-project basis at a minimum wage; 3) jobs in the places where people need them; and 4) jobs taking the people that need them as they are. 
To address the challenges that we face after the pandemic, we can expand on Minsky's framework. Combining a Green New Deal with a job guarantee, we can combat both unemployment and underemployment effectively while building a more sustainable economy. By setting dignified labor standards and a living wage, we can reduce poverty and inequality. A job guarantee must be voluntary and include those previously left behind to help fight the complex and intertwined structures of discrimination based on race, sex, gender, and nationality. Finally, a job guarantee has the potential to democratize our lives and workspaces, with a bottom-up design and a participatory democratic approach. 


\section{REFERENCES}

Case, A., and A. Deaton. 2020. Deaths of Despair and the Future of Capitalism. Princeton, NJ: Princeton University Press.

Eurostat. 2020a. "Labour Market Slack—Annual Statistics on Unmet Needs for Employment." June. Available at: https://ec.europa.eu/eurostat/statisticsexplained/index.php?oldid $=347318 \#$ Overview_of_the_underemployed_and_the_potential_ additional_labour_force.

_2020b. "Unemployment Statistics." October 30. Available at: https://ec.europa.eu/eurostat/statisticsexplained/index.php/Unemployment_statistics\#Unemployment_in_the_EU_and_the_euro_ area.

Fronstin, P., and S. A. Woodbury. 2020. "How Many Americans Have Lost Jobs with Employer Health Coverage During the Pandemic?" The Commonwealth Fund, Issue Brief, October 2020. New York: The Commonwealth Fund. Available at: https://www.commonwealthfund.org/publications/issue-briefs/2020/oct/how-many-lostjobs-employer-coverage-pandemic

Green New Deal for Europe. 2020. "COVID-19: The Time Has Come for the Green New Deal for Europe.” Website. Available at: https://www.gndforeurope.com/covid.

Kaboub, F. 2007. "Employment Guarantee Programs: A Survey of Theories and Policy Experiences.” Levy Institute Working Paper No. 498. Annandale-on-Hudson, NY: Levy Economics Institute of Bard College.

Keynes, J. M. 1997. The General Theory of Employment, Interest, and Money. New York: Prometheus Books.

Kregel, J. 2020. “Alternative Macro Policy Response for a Pandemic Recession.” Levy Institute Policy Note 2020/6. Annandale-on-Hudson, NY: Levy Economics Institute of Bard College.

Minksy, H. P. 1979. "From the New York Times Magazine." Hyman P. Minsky Archive. 406. https://digitalcommons.bard.edu/hm_archive/406.

-. 1986. "May Day 1986." Hyman P. Minsky Archive. 138.

https://digitalcommons.bard.edu/hm_archive/138.

. 1987. "A Proposal to Eliminate Welfare." Hyman P. Minsky Archive. 420.

http://digitalcommons.bard.edu/hm_archive/420.

. 1988. "Beginnings." In J. Kregel (ed.), Recollections of Eminent Economists, Volume 1, New York: Macmillian Press. 
. 1992a. "Assuming Clinton Wins." Hyman P. Minsky Archive. 164.

https://digitalcommons.bard.edu/hm_archive/164.

. 1992b. "Economics for Democrats 1." Hyman P. Minsky Archive. 183.

http://digitalcommons.bard.edu/hm_archive/183.

. 1992c. "March 4, 1933/March 4, 1992." Hyman P. Minsky Archive. 263.

https://digitalcommons.bard.edu/hm_archive/263.

. 1993a. "March 1933/March 1993." Hyman P. Minsky Archive. 264.

http://digitalcommons.bard.edu/hm_archive/264.

1993b. "The Economic Problem at the End of the Second Millenium: Creating

Capitalism, Reforming Capitalism, Making Capitalism Work." Hyman P. Minsky Archive.

101. http://digitalcommons.bard.edu/hm_archive/101.

. 1994a. "Ethics and Capitalism." Hyman P. Minsky Archive. 186.

http://digitalcommons.bard.edu/hm_archive/186.

- 1994b. "Failed and Successful Capitalisms: Lessons From the Twentieth Century."

Hyman P. Minsky Archive. 47. https://digitalcommons.bard.edu/hm_archive/47.

. 1994c. "Full Employment and Economic Growth as Objectives of Economic Policy:

Some Thoughts on the Limits of Capitalism." Hyman P. Minsky Archive. 44.

https://digitalcommons.bard.edu/hm_archive/44.

. 1995. "The Employment System, Social Security and Structure of Household Savings."

Hyman P. Minsky Archive. 57. http://digitalcommons.bard.edu/hm_archive/57.

. 1996. "Uncertainty And The Institutional Structure Of Capitalist Economies." Hyman

P. Minsky Archive. 24. http://digitalcommons.bard.edu/hm_archive/24.

—. 2008a. John Maynard Keynes. New York: McGraw-Hill.

-2008b. Stabilizing an Unstable Economy. New York: McGraw-Hill.

- 2013. Ending Poverty: Jobs, Not Welfare. Annandale-on-Hudson, NY: Levy Economics Institute of Bard College.

Mitchell, W. F. 1998. "The Buffer Stock Employment Model and the NAIRU: The Path to Full Employment." Journal of Economic Issues 32 (2): 547-55.

OECD. 2020. “OECD Economic Outlook, Interim Report September 2020.” Paris: OECD Publishing. 
Nassif Pires, L., F. Rios-Avila, M. Nikiforos, T. Masterson, and L. de Lima Xavier. 2020. "Pandemic of Inequalities." Levy Institute Public Policy Brief No. 149. Annandale-onHudson, NY: Levy Economics Institute of Bard College.

Papadimitriou, D., and H. P. Minsky. 1994. "Why Not Give Full Employment a Chance." Hyman P. Minsky Archive. 173. https://digitalcommons.bard.edu/hm_archive/173.

Rudolph, K., E. Kinnard, A. Rivera-Aguirre, D. Goin, J. Feelemyer, D. Fink, and M. Cerda. 2020. “The Relative Economy and Drug Overdose Deaths." Epidemiology 31 (April): 1.

Tcherneva, P. R. 2020. The Case for a Job Guarantee. Cambridge, UK: Polity Press.

The Hill. 2019. "Majority of Voters Support a Federal Jobs Guarantee Program.” October 30. Available at: https://hehill.com/hilltv/468236-majority-of-voters-support-a-federal-jobsguarantee-program.

Times of India. 2020. "Unemployment Rate in India: Jobs Returning, Unemployment Rate Back at Pre-Lockdown Levels." June 24. Available at: https://timesofindia.indiatimes.com/business/india-business/cmie-unemployment-rateback-to-pre-lockdown-level-of-8-5/articleshow/76540727.cms.

US Bureau of Labor Statistics. 2020a. "A Profile of the Working Poor, 2018." Washington DC: US Bureau of Labor Statistics. Available at: https://www.bls.gov/opub/reports/workingpoor/2018/pdf/home.pdf.

—. 2020b. "The Employment Situation—October 2020." Washington DC: US Bureau of Labor Statistics. Available at: https://www.bls.gov/news.release/pdf/empsit.pdf.

Workforce Promotion and Access Act (WPA Act) H.R.7477. 2020. 116th Congress (2019-20).

World Bank. 2020. "COVID-19 to Plunge Global Economy into Worst Recession since World War II.” Press Release, June 8. Available at: https://www.worldbank.org/en/news/pressrelease/2020/06/08/covid-19-to-plunge-global-economy-into-worst-recession-since-worldwar-ii.

Wray, L. R. 2016. Why Minsky Matters: An Introduction to the Work of a Maverick Economist. Princeton, NJ and Oxford: Princeton University Press.

Wray, L. R., F. Dantas, S. Fullwiler, P. R. Tcherneva, and S. A. Kelton. 2018. "Public Service Employment: A Path to Full Employment.” Levy Institute Research Project Report. Annandale-on-Hudson, NY: Levy Economics Institute of Bard College. 